\title{
Reliability and
}

\section{Maintainability Data}

for Liquid Metal Cooling Systems

\section{6th Symposium on Fusion Engineering}

\section{Lee Cadwallader}

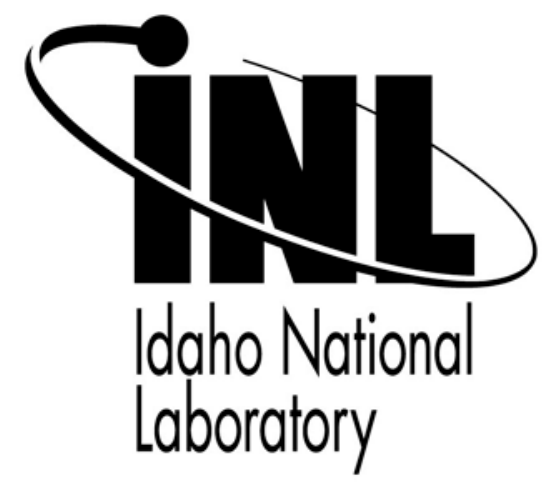

This is a preprint of a paper intended for publication in a journal or proceedings. Since changes may be made before publication, this preprint should not be cited or reproduced without permission of the author. This document was prepared as an account of work sponsored by an agency of the United States Government. Neither the United States Government nor any agency thereof, or any of their employees, makes any warranty, expressed or implied, or assumes any legal liability or responsibility for any third party's use, or the results of such use, of any information, apparatus, product or process disclosed in this report, or represents that its use by such third party would not infringe privately owned rights. The views expressed in this paper are not necessarily those of the United States Government or the sponsoring agency. 


\title{
Reliability and Maintainability Data for Liquid Metal Cooling Systems
}

\author{
Lee Cadwallader \\ Idaho National Laboratory \\ Idaho Falls, Idaho, USA \\ Lee.Cadwallader@inl.gov
}

\begin{abstract}
This paper presents component failure rate data for use in assessment of liquid metal cooling systems. Best estimate data applicable to fusion liquid metal coolants is presented. Repair times for similar components are also referenced in this work. These data support probabilistic safety assessment and reliability, availability, maintainability and inspectability analyses
\end{abstract}

Keywords—reliability; maintainability; cooling system

\section{INTRODUCTION}

One of the coolants of interest for future fusion breeding blankets is lead-lithium. As a liquid metal it offers the advantages of high temperature operation for good station efficiency, low pressure, and moderate flow rate. This coolant is also under examination for use in test blanket modules to be used in the ITER international project. To perform reliability, availability, maintainability and inspectability (RAMI) assessment and probabilistic safety assessment (PSA) of these cooling systems, component failure rate data are needed to quantify the system models. RAMI also requires repair time data. This paper presents the data that are available at present to support quantification and recommendations are given for the best values to use when quantifying system models.

\section{FAILURE RATE DATA SOURCES}

There are no known component failure rate datasets on cooling system components using lead-lithium coolant. The next best option is to use data from other liquid metals since liquid metal systems share similarities of high operating temperature, moderate flow rate, and low pressure operation. Alkali metal cooling systems have been used and have generated component failure rate data. However, coolants such as sodium often use austenitic stainless steel components, while lead-lithium can corrode this material [1]. The TRITEX experiment, a lead-lithium flow loop, used a ferritic stainless steel labeled 1.4922 [2]. This and austenitic stainless steel are different materials even though they have comparable mechanical properties. There is little failure rate data for components made from ferritic stainless steels, but one report shows that HT-9 ferritic steel failure rates are directly comparable to those of 304 stainless [3]. Failure rates of carbon steel and stainless steel piping [4] have been compared and tend to be less than an order of magnitude difference, often averaging about a half-order of magnitude difference for the same operating environment. This comparison is not wholly applicable to ferritic and austenitic stainless steel, but it is indicative that the failure rates of different steels are not widely different. As a first approximation the sodium component failure rate data can be applied to components handling $\mathrm{PbLi}$ liquid metal coolant until more pertinent data become available.

There are a few sources of component failure rate data that have been collected from operating experiences of sodiumcooled fission reactors. Boisseau [5] made estimates of failure rates for valves, motors, centrifugal and electromagnetic pumps, cold traps, heat exchangers, steam generators, and sensors based on the Rapsodie and Phenix plants as well as test loop experiences. Pamme [6] gave some KNK-II and other operating experience-based estimates for components in secondary sodium systems, including the steam generators, pumps, valves, and piping. Wood [7] published globe valve failure rates in a sodium environment using a database called the Centralized Reliability Data Organization (CREDO). Eide [8] published a large data set that also CREDO. Bott [9] published an earlier data set from CREDO data that addressed sodium valves and electromagnetic pumps. In the 1980's, the CREDO database collected operating experiences from sodium-cooled US and Japanese fission reactor facilities to support risk assessment. There is also the Experimental Breeder Reactor II risk assessment that has failure rate values from CREDO and its own operating experience [10]. Although dated, the Clinch River Breeder Reactor risk assessment can also be a resource for component failure rates [11].

John [12] presented analyst judgment failure rates for leadlithium system components, based on existing operating experiences that were presumably from sodium systems. Schnauder [13] gave tube and weld failure rates that were applied to not only helium-cooled blankets but also watercooled lead-lithium breeding blankets. Schnauder stated that the values were a combination of data from the fission 
industry with some expert judgments on multipliers to account for enhanced welding techniques and weld inspection.

There is also guidance on applying data from water-cooled fission reactors to liquid metal cooled reactors [14, 15]. Typically, water coolant system component average failure rate values are upper bounds to sodium component failure rates. With these data sources, performing probabilistic safety assessment on a liquid metal cooling system is possible.

\section{RECOMMENDED FAILURE RATES}

The quantitative data values were compared. Some data sources were not as robust as others. Definitions of the equipment failure mode and the statistical error values for the failure rates were not always given. These omissions indicate that some data values were not arrived at as diligently as they were in other datasets. In general, the Eide data [8] compared well with other values, often within a factor of 3 . The recommended failure rates for components to be used in $\mathrm{Pb}-\mathrm{Li}$ cooling systems are given in Table 1. Readers may argue that the datasets are aged, but it is noted that these sodium values have been used recently [16]. The approach is to use these data until new facilities generate enough experience data to perform a Bayesian update to these existing values.

Table 1. Recommended failure rate data for liquid metal cooling systems

\begin{tabular}{|c|c|c|c|}
\hline Component & Failure mode & Failure rate & $\begin{array}{l}\text { Error } \\
\text { factor }\end{array}$ \\
\hline \multirow[t]{6}{*}{ Manual valve } & $\begin{array}{l}\text { Fail to } \\
\text { open/close }\end{array}$ & $3.0 \mathrm{E}-04 / \mathrm{d}$ & 5 \\
\hline & Plugging & $5.0 \mathrm{E}-08 / \mathrm{h}$ & 10 \\
\hline & Internal leakage & $5.0 \mathrm{E}-08 / \mathrm{h}$ & 10 \\
\hline & Internal rupture & $1.0 \mathrm{E}-08 / \mathrm{h}$ & 10 \\
\hline & External leakage & $3.0 \mathrm{E}-07 / \mathrm{h}$ & 10 \\
\hline & External rupture & $1.0 \mathrm{E}-08 / \mathrm{h}$ & 10 \\
\hline \multirow[t]{7}{*}{$\begin{array}{l}\text { Motor } \\
\text { operated valve }\end{array}$} & $\begin{array}{l}\text { Fail to } \\
\text { open/close }\end{array}$ & $1.0 \mathrm{E}-03 / \mathrm{d}$ & 5 \\
\hline & $\begin{array}{l}\text { Spurious } \\
\text { operation }\end{array}$ & $5.0 \mathrm{E}-07 / \mathrm{h}$ & 10 \\
\hline & Plugging & $5.0 \mathrm{E}-08 / \mathrm{h}$ & 10 \\
\hline & Internal leakage & $5.0 \mathrm{E}-07 / \mathrm{h}$ & 10 \\
\hline & Internal rupture & $5.0 \mathrm{E}-08 / \mathrm{h}$ & 10 \\
\hline & External leakage & $5.0 \mathrm{E}-07 / \mathrm{h}$ & 10 \\
\hline & External rupture & $5.0 \mathrm{E}-08 / \mathrm{h}$ & 10 \\
\hline \multirow[t]{7}{*}{$\begin{array}{l}\text { Pneumatic } \\
\text { operated valve }\end{array}$} & $\begin{array}{l}\text { Fail to } \\
\text { open/close }\end{array}$ & $3.0 \mathrm{E}-03 / \mathrm{d}$ & 5 \\
\hline & $\begin{array}{l}\text { Spurious } \\
\text { operation }\end{array}$ & $3.0 \mathrm{E}-07 / \mathrm{h}$ & 10 \\
\hline & Plugging & $3.0 \mathrm{E}-08 / \mathrm{h}$ & 10 \\
\hline & Internal leakage & $1.0 \mathrm{E}-07 / \mathrm{h}$ & 10 \\
\hline & Internal rupture & $3.0 \mathrm{E}-08 / \mathrm{h}$ & 10 \\
\hline & External leakage & $1.0 \mathrm{E}-06 / \mathrm{h}$ & 10 \\
\hline & External rupture & $3.0 \mathrm{E}-08 / \mathrm{h}$ & 10 \\
\hline
\end{tabular}

Table 1. Continued

\begin{tabular}{|c|c|c|c|}
\hline Component & Failure mode & Failure rate & $\begin{array}{l}\text { Error } \\
\text { factor }\end{array}$ \\
\hline \multirow[t]{7}{*}{$\begin{array}{l}\text { Solenoid } \\
\text { operated valve }\end{array}$} & $\begin{array}{l}\text { Fail to } \\
\text { open/close }\end{array}$ & $3.0 \mathrm{E}-03 / \mathrm{d}$ & 5 \\
\hline & $\begin{array}{l}\text { Spurious } \\
\text { operation }\end{array}$ & $3.0 \mathrm{E}-07 / \mathrm{h}$ & 10 \\
\hline & Plugging & $3.0 \mathrm{E}-08 / \mathrm{h}$ & 10 \\
\hline & Internal leakage & $1.0 \mathrm{E}-07 / \mathrm{h}$ & 10 \\
\hline & Internal rupture & $3.0 \mathrm{E}-08 / \mathrm{h}$ & 10 \\
\hline & External leakage & $1.0 \mathrm{E}-06 / \mathrm{h}$ & 10 \\
\hline & External rupture & $3.0 \mathrm{E}-08 / \mathrm{h}$ & 10 \\
\hline \multirow[t]{6}{*}{ Check valve } & $\begin{array}{l}\text { Fail to open or } \\
\text { close }\end{array}$ & $1.0 \mathrm{E}-04 / \mathrm{d}$ & 5 \\
\hline & Plugging & $5.0 \mathrm{E}-07 / \mathrm{h}$ & 10 \\
\hline & Internal leakage & $5.0 \mathrm{E}-07 / \mathrm{h}$ & 10 \\
\hline & Internal rupture & $5.0 \mathrm{E}-07 / \mathrm{h}$ & 10 \\
\hline & External leakage & $5.0 \mathrm{E}-07 / \mathrm{h}$ & 10 \\
\hline & External rupture & $5.0 \mathrm{E}-07 / \mathrm{h}$ & 10 \\
\hline \multirow{3}{*}{$\begin{array}{l}\text { Pipe, } 1 \text { to } 4 \text { inch } \\
\text { diameter (per } \\
\text { foot) }\end{array}$} & Leakage & $3.0 \mathrm{E}-09 / \mathrm{h}$ & 10 \\
\hline & Rupture & $3.0 \mathrm{E}-10 / \mathrm{h}$ & 10 \\
\hline & Plugging & $1.0 \mathrm{E}-09 / \mathrm{h}$ & 10 \\
\hline \multirow{2}{*}{$\begin{array}{l}\text { Pipe, }>4 \text { inch } \\
\text { diameter (per } \\
\text { foot) }\end{array}$} & Leakage & $3.0 \mathrm{E}-09 / \mathrm{h}$ & 10 \\
\hline & Rupture & $3.0 \mathrm{E}-10 / \mathrm{h}$ & 10 \\
\hline \multirow[t]{2}{*}{ Strainer/filter } & Plugging & $3.0 \mathrm{E}-06 / \mathrm{h}$ & 10 \\
\hline & Fail open & $3.0 \mathrm{E}-06 / \mathrm{h}$ & 10 \\
\hline \multirow[t]{4}{*}{ Cold trap } & Fail to trap & $5.0 \mathrm{E}-07 / \mathrm{h}$ & 10 \\
\hline & External leakage & $5.0 \mathrm{E}-07 / \mathrm{h}$ & 10 \\
\hline & External rupture & $5.0 \mathrm{E}-07 / \mathrm{h}$ & 10 \\
\hline & Plugging & $5.0 \mathrm{E}-07 / \mathrm{h}$ & 10 \\
\hline \multirow{4}{*}{$\begin{array}{l}\text { Motor driven } \\
\text { centrifugal } \\
\text { pump } \\
\end{array}$} & Fail to start & $5.0 \mathrm{E}-03 / \mathrm{d}$ & 5 \\
\hline & Fail to run & $5.0 \mathrm{E}-05 / \mathrm{h}$ & 10 \\
\hline & External leakage & $3.0 \mathrm{E}-06 / \mathrm{h}$ & 10 \\
\hline & External rupture & $5.0 \mathrm{E}-07 / \mathrm{h}$ & 10 \\
\hline \multirow{4}{*}{$\begin{array}{l}\text { Electromagnetic } \\
\text { pump }\end{array}$} & Fail to start & $3.0 \mathrm{E}-03 / \mathrm{d}$ & 5 \\
\hline & Fail to run & $1.0 \mathrm{E}-05 / \mathrm{h}$ & 10 \\
\hline & External leakage & $3.0 \mathrm{E}-06 / \mathrm{h}$ & 10 \\
\hline & External rupture & $5.0 \mathrm{E}-07 / \mathrm{h}$ & 10 \\
\hline \multirow[t]{5}{*}{$\begin{array}{l}\text { Intermediate } \\
\text { heat exchanger }\end{array}$} & $\begin{array}{l}\text { Shell external } \\
\text { leakage }\end{array}$ & $1.0 \mathrm{E}-06 / \mathrm{h}$ & 10 \\
\hline & $\begin{array}{l}\text { Shell external } \\
\text { rupture }\end{array}$ & $1.0 \mathrm{E}-06 / \mathrm{h}$ & 10 \\
\hline & $\begin{array}{l}\text { Tube bank small } \\
\text { leak }\end{array}$ & $1.0 \mathrm{E}-06 / \mathrm{h}$ & 10 \\
\hline & Tube bank leak & $1.0 \mathrm{E}-06 / \mathrm{h}$ & 10 \\
\hline & $\begin{array}{l}\text { Tube bank } \\
\text { rupture }\end{array}$ & $1.0 \mathrm{E}-06 / \mathrm{h}$ & 10 \\
\hline
\end{tabular}


Table 1. Continued

\begin{tabular}{|l|l|l|l|}
\hline Component & Failure mode & Failure rate & $\begin{array}{l}\text { Error } \\
\text { factor }\end{array}$ \\
\hline $\begin{array}{l}\text { Intermediate } \\
\text { heat exchanger }\end{array}$ & $\begin{array}{l}\text { Tube bank } \\
\text { plugging }\end{array}$ & $1.0 \mathrm{E}-06 / \mathrm{h}$ & 10 \\
\hline $\begin{array}{l}\text { Steam } \\
\text { generator }\end{array}$ & $\begin{array}{l}\text { Shell external } \\
\text { leakage }\end{array}$ & $1.0 \mathrm{E}-06 / \mathrm{h}$ & 10 \\
\hline & $\begin{array}{l}\text { Tube bank small } \\
\text { leak }\end{array}$ & $5.0 \mathrm{E}-06 / \mathrm{h}$ & 10 \\
\hline & $\begin{array}{l}\text { Tube bank } \\
\text { medium leak }\end{array}$ & $1.0 \mathrm{E}-06 / \mathrm{h}$ & 10 \\
\hline & $\begin{array}{l}\text { Tube bank large } \\
\text { leak }\end{array}$ & $3.0 \mathrm{E}-07 / \mathrm{h}$ & 10 \\
\hline Tank & External leakage & $1.0 \mathrm{E}-06 / \mathrm{h}$ & 10 \\
\hline & External rupture & $1.0 \mathrm{E}-07 / \mathrm{h}$ & 10 \\
\hline
\end{tabular}

Notes: /d indicates per demand to operate. /h indicates per operating hour

\section{REPAIR TIME DATA}

There are not many sources for hands-on repair times of liquid metal cooling system components. Like component failure rates described above, the majority of data available are from sodium coolant systems. Cadwallader [17] has a bibliography of documents that discuss some repair times for mechanical and electrical equipment used in nuclear facilities, including sodium-cooled fission reactors. There are some other values in the literature for sodium cooling systems $[6,11,12,16,18]$. Table 2 gives some representative repair times. It should be noted that for sodium systems, often a "freeze plug" is used, where fans are used to force room air over a section of pipe so that the pipe cools and sodium freezes in a small, localized section of the pipe to form a coolant plug. Setting up fans and establishing a freeze plug (and allowing reheating of the plug metal) adds some time to a repair of piping, flanges, valves, instruments, etc.

Table 2. Some component repair times [16,17]

\begin{tabular}{|l|l|l|}
\hline Component & Failure Mode & $\begin{array}{l}\text { Repair Time } \\
\text { (days) }\end{array}$ \\
\hline Tank & External leak & 15 \\
\hline Piping & External leak & 15 \\
\hline Heat exchanger & Shell leak & 15 \\
\hline Heat exchanger & Tube leak & 30 \\
\hline Pneumatic valve & External leak & 3 \\
\hline Manual valve & External leak & 0.167 \\
\hline $\begin{array}{l}\text { Electromagnetic } \\
\text { pump }\end{array}$ & $\begin{array}{l}\text { External leak, } \\
\text { replace }\end{array}$ & 33 \\
\hline
\end{tabular}

Sazonov [19] described repair activities on the USSR submarine reactors using lead-bismuth coolant (there were several Alfa class submarines with lead-bismuth cooled fission reactors [20]). The small reactor compartments in the submarines restricted the space available for maintenance work, making the work more difficult. Sazonov stated that there were positive features of the lead-bismuth coolant: low induced gamma activity, chemical inertness of the coolant (oxidation is a safety issue with this coolant [21]), no significant spills due to the high melting point, and no liquid radioactive waste as compared to water-cooled reactors. Sazonov also stated that coolant valves had no failures and that none of the major equipment items (e.g., pumps) in these reactor installations required significant reconditioning. There were some minor coolant leaks when samples were taken for chemical analysis; this was believed to be due to human error. Minor repairs to cooling systems were performed under hot conditions with no coolant flow but using a steam source on shore to maintain the metal coolant temperature above freezing; applying the steam source was stated to be a laborintensive and complex procedure, but necessary to avoid the pipe stress issues with freezing and thawing lead-bismuth. Nitrogen was used as a gas blanket to prevent coolant oxidation in air. Pumps had gaskets and removable parts replaced (e.g., impellers), and oxygen sensors in the coolant were also replaced. Sazonov did not give task time durations or counts of workers needed for these activities, but given the complexity of the task (rigging temporary steam heat piping from the shore and nitrogen gas blanketing) compared to setting up fans to freeze-plug sodium coolant, it is obvious that the times for repairs of heavy liquid metal system components in submarine reactors were greater than those for sodium coolant. Analyst judgment is needed when applying repair time values in RAMI studies of PbLi cooling systems.

\section{CONCLUSIONS}

The information presented and referenced in this paper will give good support to analysts who are assessing the probabilistic safety or RAMI of a liquid metal cooling system. These data can be used until enough operating experience with liquid metal cooling systems has accumulated to allow a statistical Bayesian update to the values.

\section{ACKNOWLEDGMENT}

This material is based upon work supported by the U. S. Department of Energy Office of Science, Office of Fusion Energy Sciences, under the DOE Idaho Operations Office contract number DE-AC07-05ID14517.

\section{REFERENCES}

[1] V. Coen, H. Kolbe, L. Orecchia, M. Della Rossa, "Corrosion of Cr-Mn based austenitic stainless steels by lithium-lead eutectic Pb-17Li," Fus. Eng. Des., vol. 14, pp. 309-319, 1991.

[2] H. Feuerstein, H. Gräbner, and G. Kieser, "TRITEX, a forced convection loop with Pb-17Li," J. Nucl. Mat., vol. 155-157, pp. 520523, 1988.

[3] L. Cadwallader, In-Vessel Coil Material Failure Rates for ITER Design Use, INL/EXT-13-28031, Idaho National Laboratory, January 2013.

[4] Pipe Rupture Frequencies for Internal Flooding PRAs, revision 1, EPRI TR-1013141, Electric Power Research Institute, Palo Alto, California, March 2006.

[5] J. Boisseau, J. Dorey, F. Hedin, C. Le Floch, "Failure Rate Evaluation for Different Components Operating in Sodium, Based on Operating Experience of the Rapsodie and the Phenix Reactors and the Test 
Loops," Proceedings of the LMFBR Topical Meeting, Lyon, France, July 19-23, 1982, pp. II-677 - II-687.

[6] H. Pamme, "Comparative Availability and Reliability Assessment of Design Options for the Secondary Sodium Loops of the EFR," in V. Colomari, editor, Reliability Data Collection and Use in Risk and Availability Assessment, Berlin: Springer-Verlag, pp. 563-577, 1989.

[7] D. H. Wood, M. S. Smith, J. D. Drischler, "Motor-Operated Globe Valve performance in a Liquid Sodium Environment," Bi-annual Nuclear Energy Meeting of the American Nuclear Society and the American Society of Mechanical Engineers, San Diego, California, August 23-26, 1992.

[8] S. A. Eide, S. V. Chmielewski, T. D. Swantz, "Generic Component Failure Data Base for Light Water and Liquid Sodium PRAs," EGGSSRE-8875, February 1990.

[9] T. F. Bott, P. M. Haas, J. J. Manning, "Sodium Component Reliability Data Collection at CREDO," CONF-790602-62, 1979.

[10] Experimental Breeder Reactor II Level 1 Probabilistic Risk Assessment, EBR-II PRA, revision 2, Argonne National Laboratory, June 1991.

[11] S. Z. Bruske et al., "Clinch River Breeder Reactor Plant Probabilistic Risk Assessment - Phase I," EGG-EA-6162, Idaho National Engineering Laboratory, January 1983.

[12] H. John et al., "DEMO-Relevant Test Blankets for NET/ITER, Part 1: Self-cooled Liquid Metal Breeder Blanket, Volume 2: Detailed Version," KfK-4908, Kernforschungszentrum Karlsruhe, December 1991, p. 95

[13] H. Schnauder, C. Nardi, M. Eid, "Comparative availability analysis fo the four European DEMO blanket concepts in view of the selection exercise," Fus. Eng. Des., vol. 36, pp. 343-365, 1997.
[14] H. L. Thaggert, I. M. Jacobs, "Component Failure Rates Applicable to LMFBRs as Derived from LER Data," Nucl. Safety, vol. 24, pp. 801$809,1983$.

[15] S. L. Painter, H. E. Knee, B. Humphrys, "CREDO Analysis: A Comparison of Liquid Metal and Water Valve Reliabilities," CONF850713-4, July 1985.

[16] A. J. Arul, C. S. Kumar, S. Athmalingam, O. P. Singh, K. S. Rao, "Reliability analysis of safety grade decay heat removal system of Indian prototype fast breeder reactor," Ann. Nucl. Energy, vol. 33, pp. 180-188, 2006.

[17] L. C. Cadwallader, Review of Maintenance and Repair Times for Components in Technological Facilities, INL/EXT-12-27734, Idaho National Laboratory, November 2012.

[18] K. P. Johnson, J. D. Leman, H. Lawroski, A. Amorosi, "Assessment of Maintainability of LMFBR Designs," EPRI NP-1714, Electric Power Research Institute, Palo Alto, California, February 1981.

[19] V. K. Sazonov et al., "Technology and Experience of Repair Works and Refuelings for the Nuclear Power Installations with Lead-Bismuth Coolant," Proceedings of the Conference on Heavy Liquid Metal Coolants in Nuclear Technology, volume 2, Obninsk, Russian Federation, October 5-9, 1998, IPPE, pp. 599-605, 1999.

[20] N. Polmar and J. S. Noot, Submarines of the Russian and Soviet Navies, 1718-1990, Naval Institute Press, Annapolis, Maryland, pp. 196-197, 1991.

[21] B. F. Gromov, O. G. Grigoriev, A. V. Dedoul, G. I. Toshinsky, V. S. Stepanov, L. B. Nikitin, "The analysis of operating experience of reactor installations using lead-bismuth coolant and accidents happened," Proceedings of the Conference on Heavy Liquid Metal Coolants in Nuclear Technology, volume 1, Obninsk, Russian Federation, October 5-9, 1998, IPPE, pp. 60-66, 1999. 